\title{
SCRUTINY ON PHYSICAL PROPERTIES OF SAWDUST FROM TROPICAL COMMERCIAL WOOD SPECIES: EFFECTS OF DIFFERENT MILLS AND SAWDUST'S PARTICLE SIZE
}

\author{
Rizki Maharani ${ }^{1,2,3}$, Tamai Yutaka ${ }^{1,4}$, Takashi Yajima ${ }^{1,4}$ and Terazawa Minoru ${ }^{4}$
}

\begin{abstract}
Physical properties of sawdust (i.e. particle size distribution, particle density, porosity, and water retention) from five tropical commercial wood species (Shorea leprosula, Dryobalanops lanceolata, Dipterocarpus cornutus, Shorea laevis, and Eusideroxylon zwageri) as prepared in various mill types (i.e. handsaw, sawmill, and milling) were analyzed. This study aims to look into the relationship and interconnected between the use of different mill types, density of wood species origin and physical properties of the resulting sawdust. Generally, different mill types produced sawdust with different particle size distributions. The use of a handsaw produced a higher proportion of oversized particles (OS) and coarser particle size (CPS) than that of sawmill and milling, while also commonly producing the lowest proportion of fine particle size (FPS). For each wood species, the proportion of OS was lower than that of CPS and FPS. In addition, particle density and water retention produced by handsaw in CPS as well as FPS was the smallest, followed in an increasing order sawmill and milling. Porosity of CPS and FPS was the highest in handsaw-cut sawdust, followed in a decreasing order sawmill and milling cut sawdust. This study showed that the different mill types and particle size influenced the physical properties of sawdust. Further, analysis of influential factors on porosity and water retention using General Linear Model revealed that particle density inflicted a strong influence on porosity, as did particle size on water retention.
\end{abstract}

Keywords: physical properties, sawdust, wood species origin, different mills, particle size

\section{INTRODUCTION}

Sawdust refers to the tiny-sized and powdery wood waste produced by the sawing of wood. The size of sawdust particles depends on the kinds of wood from which the sawdust is obtained and also on the size of the saw teeth (Afuwape, 1983). About 10-13\% of the total volume of the wood log is reduced to sawdust in milling operations; this sawdust generally depends largely on the average width

\footnotetext{
${ }^{1}$ Laboratory of Forest Resource Biology, Division of Environmental Resources, Graduate School Agriculture, Hokkaido University, N-9, W-9, Kita-ku, Sapporo 060-8589, Hokkaido, Japan.

${ }^{2}$ Dipterocarps Research Center, Forestry Research and Development Agency, Ministry of Forestry, Jalan A.W. Syahrani 68 Samarinda 75119, East Kalimantan, Indonesia.

${ }^{3}$ Corresponding author. E-mail: rizma_annisa@yahoo.com

${ }^{4}$ Research Faculty of Agriculture, Hokkaido University, Sapporo 060-8589, Hokkaido, Japan.
} 
of the saw kern and the thickness of the timber sawed (Paulrud et al., 2002). Generally, utilization of the generated tropical commercial wood sawdust becomes an urgent problem since alternative to clean with by just employing the so-called conventional incineration may produce environmentally hazardous pollutants such as polychlorinated dibenzo-dioxins and dibenzo-furans (Terazawa, 2003; Frombo et al., 2009). In addition, sawdust being essentially a ligno-cellulosic material, is not easily deteriorated but rather stable on recalcitrant in the environment, and rarely produces odor during its long-term biodegradation process (Terazawa et al., 1999; Zavala et al., 2005).

In the field of compost science, sawdust has been referred to not only as a bulking agent but also as biomass material for the manufacture of woody compost (Horisawa et al., 1999; Zavala et al., 2004). The benefits of using sawdust as a woody biomass in compost manufacture are its favorable physical properties such as low apparent specific gravity (density), high porosity, high water retention, moderate water drainage, high bacteria tolerance, and biodegradability at an acceptable rate; in this way sawdust-composting process can then be enhanced (Kitsui and Terazawa, 1999). Physical properties of sawdust can also be modified by combining the sawdust particles of various sizes in particular proportion (Houghton et al., 2002; Agnew and Leonard, 2003; Dikinya et al., 2006). This modification creates an ideal environment to remove moisture from sawdust waste efficiently, and also for aerobic bacteria to thrive and decompose waste effectively into carbon dioxide and water without generating odor (Terazawa $e t$ al., 1999). Improvement of our knowledge about the physical properties of sawdust signifies the first step for its rational utilization.

Regarding the utilization of woody biomass into compost, it is important to pay attention to its physical properties due to the fact that kinds of raw materials, the mill type, and the type of sieve affect these properties (Himmel et al., 1985). In order to produce the most efficient physical properties of the sawdust, simple characterization methods should be developed. This study was carried out to determine such appropriate physical properties including particle size distribution, particle density, porosity and water retention of sawdust accounting for different mill types and sizes of sawdust particle. With this in mind, variations in physical properties of sawdust were examined according to different mill types by taking into consideration five wood species of different densities. Sawdust samples as prepared from five tropical commercial wood species, i.e.meranti merah (Shorea leprosula), kapur (Dryobalanops lanceolata), keruing (Dipterocarpus cornutus), bangkirai (Shorea laevis) and ulin (Eusideroxylon zwageri) were collected directly from wood industries situated in East Kalimantan, Indonesia. These species were selected because they are regarded representative of species available on a commercial basis and also potentially abundant in the production forest in East Kalimantan (MFoR, 2007). We analyzed whether mill types and variation in sawdust particle size could reflects its physical properties. 


\section{MATERIALS AND METHODS}

\section{A. Raw Materials}

Commercial woods used as raw materials were obtained from five tropical tree species (i.e. S. leprosula, D. lanceolata, D. cornutus, S. laevis and E. zwageri), and their varying wood densities (without bark at a moisture content of 7-16\%) were determined in a dimension measuring $5^{\prime} 5^{\prime} 5 \mathrm{~cm}$ (green condition). It was expressed as green mass over green volume $\left(\mathrm{g} \mathrm{cm}^{-3}\right)$ in accordance with Johnson et al. (2003), as presented in Table 1.

Table 1. Variation in the density of five tropical wood species.

\begin{tabular}{llll}
\hline & \multicolumn{3}{c}{ Wood density $\left(\mathrm{g} \mathrm{cm}^{-3}\right)$} \\
\cline { 2 - 4 } \multicolumn{1}{c}{ Wood species } & Mean & SD & Range \\
\hline Shorea leprosula & 0.51 & 0.02 & $0.47-0.53$ \\
Dryobalanops lanceolata & 0.71 & 0.01 & $0.69-0.72$ \\
Dip terocarpus cornutus & 0.84 & 0.03 & $0.80-0.88$ \\
Shorea laevis & 0.96 & 0.02 & $0.93-0.99$ \\
Eusidreoxylon zwageri & 1.20 & 0.05 & $1.17-1.2$ \\
\hline
\end{tabular}

Notes: SD: standard deviation, density: gram weight/green volume, number of sample (replication): 6.

\section{B. Sawdust Preparations}

Sawdust was produced by sawing each wood species (Table 1) using three different mill types, i.e. handsaw machine (type D126 HITACHI, made in Japan) with circular saw knife thickness of about $3.8 \mathrm{~mm}$, sawmill (type JB 3074-82, made in Taiwan) with circular saw knife thickness of $3 \mathrm{~mm}$, and milling machine (type CE TUV, made in Germany) with thickness of band saw size of $2 \mathrm{~mm}$.

\section{Sieve Analysis for the Particle Size Distribution}

For each mill, the resulting sawdust was classified in its particle size distribution into three fractional sizes: i.e. oversized, coarse and fine using the sieving machine called "Fritcsh" (made in Germany). The classification, which was consistent with oversized (OS) was used for particle size $<24$ mesh $(>710 \mu \mathrm{m})$, coarse particle size (CPS) for particle size 24-60 mesh (350-710 $\mu \mathrm{m})$, and fine particle size (FPS) for 60-80 mesh $(177-350 \mu \mathrm{m})$. In accordance with the objective of this study, the proportions of OS, CPS and FPS were determined by weight, and further OS particles were excluded, due to being the lowest in proportion, and with a high variation in their size. 


\section{Particle Density}

Particle density of the sawdust was determined by the methods employed by Araki and Terazawa (2004) and Rühlmann et al. (2006). It was calculated by adding the sawdust $\left(=100 \mathrm{~cm}^{3}\right)$ into a graduated volumetric cylinder to reach the marked $100 \mathrm{~cm}^{3}$ volume $\left(V_{0}\right)$, and its weight $(\mathrm{g})$ could then be known by subtracting the combined weight of sawdust and volumetric cylinder $(W b)$ with the weight of empty volumetric cylinder $(\mathrm{Wa})$ alone. The sawdust - particle density could then be calculated using the formula:

$$
\text { Particle density }\left(\mathrm{g} \mathrm{cm}^{-3}\right)=(W b-W a) / V o
$$

\section{E. Porosity}

Porosity of sawdust can be defined as a measure of void volume of sawdust grains, composed principally of inter-spaces among and intra-spaces within the particles (Agnew and Leonard, 2003; Bouma et al., 2003a), or the percentage of sawdust volume occupied by air and water that filled voids (Baker et al., 1998). The percentage of porosity was determined by Horisawa et al. (1999)'s method. Sawdust with apparent volume of 100 $\mathrm{cm}^{3}$ and known weight (Ws in grams) was at first placed in a volumetric cylinder. Tap water was then poured gently into it until the surface of water reached a marked line at the $100 \mathrm{~cm}^{3}$ level. A meshed top as a stopper was equipped at the $100 \mathrm{~cm}^{3}$ level so that the sawdust, mostly floating on water, would not go beyond its surface. Porosity was expressed as the following formula:

$$
\text { Porosity }(\%)=(\mathrm{Va} / \mathrm{Vo}) \times 100
$$

where $\mathrm{Va}$ and $V o$ are consentively the volume of poured water $\left(\mathrm{cm}^{3}\right)$ together with the water in the sawdust, and the volume of sawdust $\left(=100 \mathrm{~cm}^{3}\right)$ respectively. The volume of poured water, with the water in the sawdust could be calculated using the formula:

$$
V a\left(\mathrm{~cm}^{3}\right)=W c o m b-W s-W v s
$$

where Wcomb is the combined weight (grams) of volumetric cylinder, sawdust particle, and poured water (gram); Ws is the weight (gram) of sawdust particles (oven-dry weight equivalent), and Wvs is the weight (grams) of volumetric cylinder. Note that the density of tap water was assumed to be a unity $\left(1 \mathrm{gram} \mathrm{cm}^{-3}\right)$.

\section{F. Water Retention}

In compost science, water retention is defined as the ability of compost to hold water for a period that is longer than infiltration, or the ability of compost to hold and retain water (Agnew and Leonard, 2003; Bouma et al., 2003b). This definition is also applied to the sawdust, since it is related to the compost items. The percentage of water retention was determined by Horisawa et al (1999)'s method. A glass column (inner diameter $50 \mathrm{~mm}$ ) equipped with a faucet at its bottom part was packed with $100 \mathrm{~cm}^{3}$ apparent 
volume of sawdust, and the faucet was closed. A hundred milliliters of water was poured in gently. Ten minutes later, the faucet was opened to drain the water gravimetrically until no more drainage of water was observed. Water retention was expressed as follows:

$$
\text { Water retention }(\%)=\left\{\left(V b+V_{c}-V d\right) / V_{o}\right\} \times 100 \text {. }
$$

where $\mathrm{Vb}$ is the volume of poured water $\left(=100 \mathrm{~cm}^{3}\right)$; Vc is the volume of water in $100 \mathrm{~cm}^{3}$ of sawdust (related to the moisture content of the sawdust); Vd is the volume of drained water $\left(\mathrm{cm}^{3}\right)$; and Vo is the volume of apparent sawdust $\left(=100 \mathrm{~cm}^{3}\right)$.

\section{G. Statistical Analysis}

To determine which sawdust characteristics inflicted influence the most on its porosity and water retentions a generalized linear model (GLM) was performed, taking different mill types, particle size classes, wood density that represent wood species, and particle densities as explanatory variables elaboration sawdust characteristics. The porosity and water retention of the sawdust were regarded as dependent variables for each wood species. The replication was done six times. Analysis for the GLM test was conducted using JMP 7.0.1 (SAS Institute Inc, 2007).

\section{RESULTS AND DISCUSSION}

\section{A. Particle Size Distribution}

The particle size distributions of sawdust produced by three different mills generally showed almost a similar pattern with input to proportion of particle size distribution regardless of wood species (Figure 1). The proportion of OS was lower than that of CPS and FPS regardless tree species (Figure 1) or wood density (Table 1). However, comparing the proportions of particle size distribution for each mill within tree species revealed a different pattern. The average of particle size distribution with \pm standard deviation (SD) combined for all sawdust samples from five different wood densities showed that particle size distribution of CPS produced by handsaw was $60.4 \pm 2.6 \%$, which was the highest, followed in a decreasing order by sawmill $(52.6 \pm 1.5 \%)$ and by milling $(25.6 \pm 2.1 \%)$. Consequently, this pattern affects the proportion of particle size in other classes, e.g. FPS. The proportion of particle size distribution in FPS produced by handsaw was the smallest $(30.0 \pm 1.2 \%)$, followed in an increasing order by sawmill $(37.2 \pm 1.3 \%)$ and by milling $(71.8 \pm 1.9 \%)$ (Figure 1$)$. It can be concluded that the mill types influenced particle size distribution (OS, CPS, and FPS). A similar pattern was reported by Paulrud et al. (2002) and Bergström et al. (2008) which stated that particle size distribution has been associated with the size of sawdust and the mill types that are used for producing sawdust. Moreover, Himmel et al. (1985) and Houghton (2002) reported that the size of knife used will affect particle size distribution, and that increasing the size of knife had also been associated with larger particle size. In this 
study, the handsaw with the thickest knife $(3.8 \mathrm{~mm})$ followed in a decreasing order by sawmill $(3 \mathrm{~mm})$ and by milling $(2 \mathrm{~mm})$ produced proportion of CPS higher than that of sawmill and milling. Thus it is logical that particle size distribution of sawdust samples (OS, CPS, and FPS) which are processed by a different mills and knife sizes appears to be more consistent with input to the proportion of OS, CPS, and FPS among different wood species with their varying density (Figure 1 and Table 1).

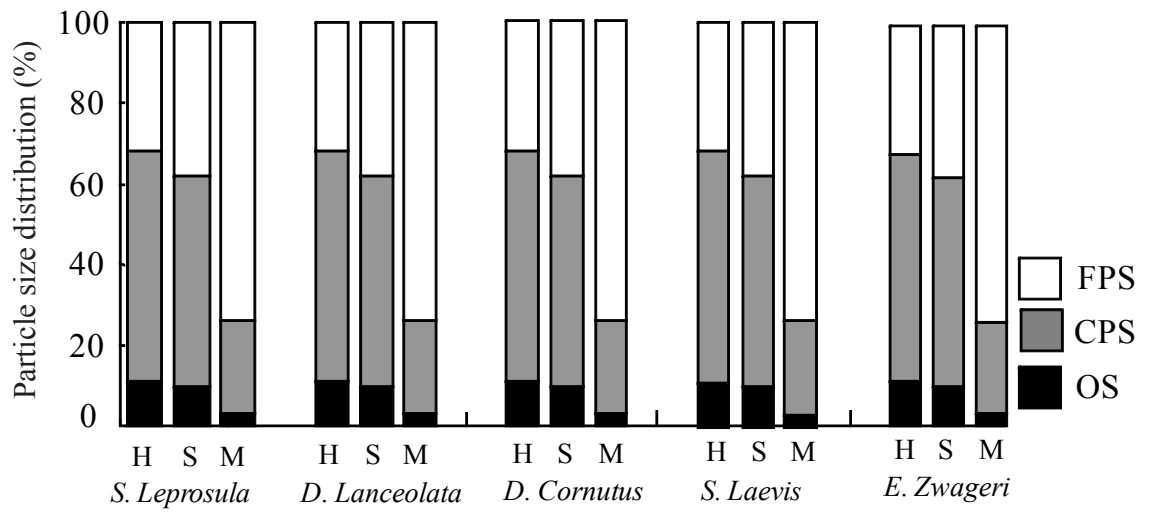

Wood species of origin

Figure 1. Particle size distribution (OS, CPS, and FPS) of sawdust samples produced from five tropical wood species using different mill types: i.e. handsaw $(\mathrm{H})$, sawmill $(\mathrm{S})$, and milling $(\mathrm{M})$.

\section{B. Particle Density}

A comparison result of particle density among different mills showed a similar pattern for each wood species with the particle density produced by handsaw was the smallest both in CPS and in FPS, followed in an increasing order by sawmill and by milling (Figures 2a,b). Combining the value of particle density for all sawdust from five different wood species in each different mill showed that the average \pm SD of the particle density produced by handsaw $\left(C P S=0.22 \pm 0.02 \mathrm{~g} \mathrm{~cm}^{-3} ; \mathrm{FPS}=0.25 \pm 0.07 \mathrm{~g}\right.$ $\mathrm{cm}^{-3}$ ) was smaller than that by sawmill $\left(C P S=0.23 \pm 0.07 \mathrm{~g} \mathrm{~cm}^{-3} ; \mathrm{FPS}=0.25 \pm 0.06 \mathrm{~g}\right.$ $\left.\mathrm{cm}^{-3}\right)$ and by milling $\left(\mathrm{CPS}=0.25 \pm 0.06 \mathrm{~g} \mathrm{~cm}^{-3}\right.$; FPS $=0.32 \pm 0.11 \mathrm{~g} \mathrm{~cm}^{-3}$ ) (Figure 2). This pattern is probably due to variation in knife size accounted on each mill. Milling with the smallest size of knife produced a finer particle size sawdust than sawmill and handsaw both with greater knife size. This study also demonstrated the strong effect of wood density and particle size classes on particle density of sawdust. It can be seen in Figure 2, that both CPS and FPS for all different mill types showed that $S$. leprosula, with the lowest wood density $\left(0.51 \pm 0.02 \mathrm{~g} \mathrm{~cm}^{-3}\right)$ that produce sawdust with the smallest particle density, while $E$. zwageri, with the highest wood density $(1.20 \pm 0.05$ 
$\mathrm{g} \mathrm{cm}^{-3}$ ) afforded the highest particle density of its corresponding sawdust (Table 1, Figure 2). The patterns of wood density differences corresponded well to those of particle density. High wood density tended to produce sawdust with higher particle density, this occurred to CPS as well as FPS (Figures 2a, b). This pattern could be explained by hypothesizing that high wood density will influence the average sawdust weight. In another case, but still related with a relatively larger particle size of CPS, tended to have a relatively lower particle density than that of FPS (Figures 2a, b). This is because the large-size particles (CPS) are less likely to pack together, and therefore provide air space more readily, thereby lowering their particle density and vice versa for the smaller-size particle (FPS). This situation applied to all sawdust from the five different wood species. A previous study by Coudray et al. (2009) supported this result during measurement of fine aerosol fraction from wood, where the particle densities decreased consistently with the increase in particle size. Although it has been generally accepted that wood density influences particle density, this study shows that different mill and particle size classes also influence particle density for each tree species.
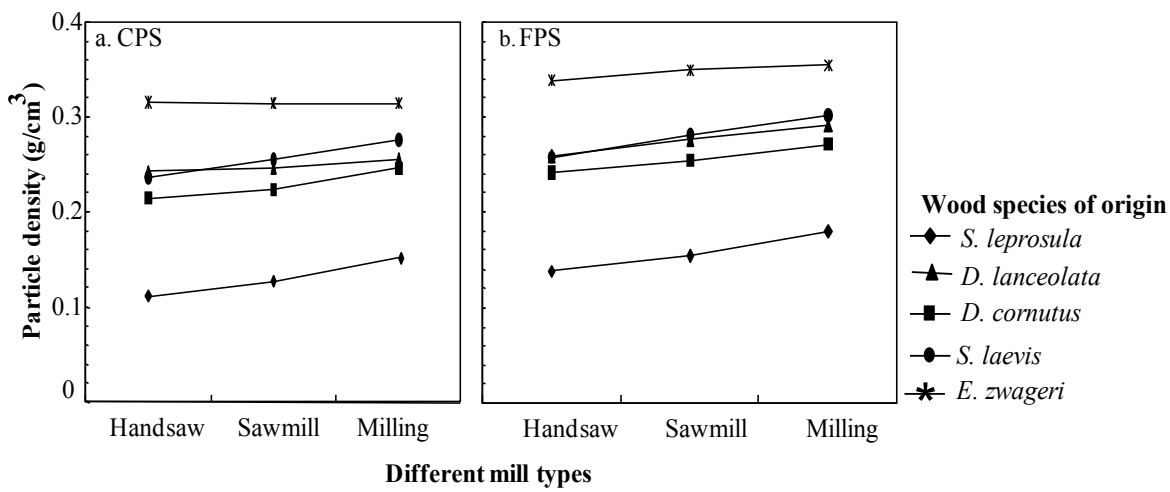

Figure 2. Particle density $\left(\mathrm{g} \mathrm{cm}^{-3}\right)$ of sawdust samples from five tropical wood species using different mill types and elaborated by particle size classes: CPS (a), and FPS (b). The density of wood species origin refers to Table 1.

\section{Porosity}

Analysis of variance (GLM) revealed that all the variables tested, i.e. mill types, particle size, wood density, and sawdust's particle density significantly affected the porosity (Table 2). Further, a comparison of porosity patterns between different mills for each tree species showed slight differences in CPS as well as in FPS. Related with such combining the value of porosity for all tree species showed that the average porosity of sawdust particle (CPS and FPS) produced by handsaw (CPS = 77.4 $\pm 7.5 \%$; FPS $=74.7$ $\pm 7.4 \%)$ was higher than that by sawmill (CPS $=76.2 \pm 6.6 \%$; FPS $=73.1 \pm 6.5 \%)$ and by milling $(\mathrm{CPS}=73.9 \pm 4.2 \%$; FPS $=71.0 \pm 4.1 \%)($ Figure 3$)$. The possible explanation 
is that the sizes of knife for handsaw, sawmill, and mills are in decreasing order, i.e. 3.8 $\mathrm{mm}, 3.0 \mathrm{~mm}$, and $2.0 \mathrm{~mm}$, respectively. As described before the larger knife size, then the larger particle size, thereby inflicting the greater porosity in the corresponding sawdust particle, and vice versa for the smaller knife size. This situation occurred to CPS as well as FPS (Figures 3a, b). In addition, a comparison between wood species for all different mills in porosity showed that S. leprosula with the lowest wood density and sawdust's particle density, was the highest in porosity, while E. zwageri, with the highest wood and sawdust's particle density was the lowest in porosity (Table1, Figure 3). Since particle density is influenced by wood density (Table 1, Figure 2), an increase of wood density in tropical wood species has been associated with either an increase of sawdust's particle density or a decreased volume of sawdust's pores. In addition, the pore presence in wood species origin with greater density is usually less abundant than that with lower density, and vice versa. Thus it is logical that sawdust with high wood density tends to have low porosity. Further, the porosity of CPS's sawdust for each species was greater than that of FPS's sawdust (Figures 3a, b). It can then be understood that, as described earlier, the CPS tends to have more air space (inter space among particles than FPS's sawdust).

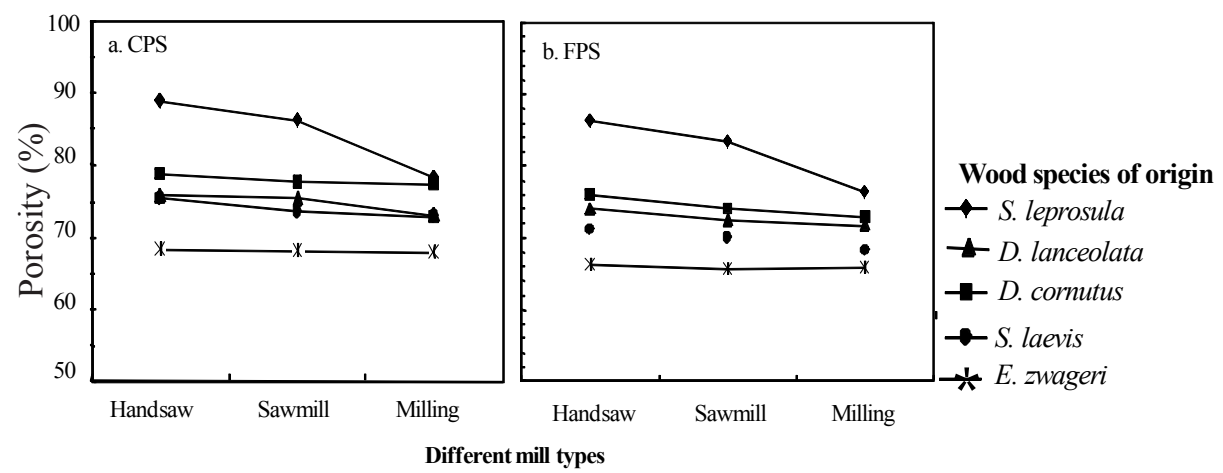

Figure 3. Porosity (\%) of sawdust samples from five tropical wood using different mill types and specified by particle size classes: CPS (a), and FPS (b).

\section{Water Retention}

Analysis of variance using GLM revealed that mill types did not significantly affect both water retention and sawdust's particle density (Table 2). However, water retention was significantly affected by sawdust's particle density $(\mathrm{P}<1 \%)$, and by wood density (P $<5 \%$ ). Comparisons of water retention percentages of CPS to those of FPS generally showed a similar pattern for each mill type. Combining the value of water retention for different wood species showed that the water retention of sawdust in CPS as well as in FPS that were produced by handsaw was smaller (CPS $=33.1 \pm 8.9 \%$; FPS = $68.7 \pm 5.6 \%)$ than that of by sawmill (CPS $=38.7 \pm 8.7 \%$; FPS $=71.2 \pm 5.3 \%)$ and by milling $(\mathrm{CPS}=42.9 \pm 9.6 \%$; FPS $=75.1 \pm 4.0 \%)$ (Figure 4$)$. This situation relates to 
the fact the particle density size of sawdust produced by handsaw was greater than that by consecutively sawmill and milling. Further, interestingly, the value of water retention in CPS was significantly lower than that of FPS for all wood species in each mill type (Figure 4). The scatter panel of water retention on which CPS and FPS are plotted shows the distribution of water retention values for all different mill types and wood species in CPS was smaller than that in FPS. This figure again indicated that the differences in particle size between CPS and FPS have a strong influence on water retention. This study has demonstrated that smaller particle size in FPS than that of CPS leads to increased high values of water retention in FPS. This may be due to the fact the decrease in particle size of sawdust (i.e. FPS) brought out the increase in their surface area, thereby enhancing the adhesion between particles and water mass and hence augmenting water retention. The situation would be on the contrary for the larger-particle sawdust (CPS). Figures $4 \mathrm{a}$ and $4 \mathrm{~b}$ show the degree of influence regarding the different particle size classes (CPS and FPS) on water retention. A previous study on the influence of particle size in soil and compost reported that particle size has strong influence on water retention; smaller particle size tends to keep higher water attraction than larger particle size (Hwang et al., 2002; Agnew and Leonard, 2003; Dikinya et al., 2006).

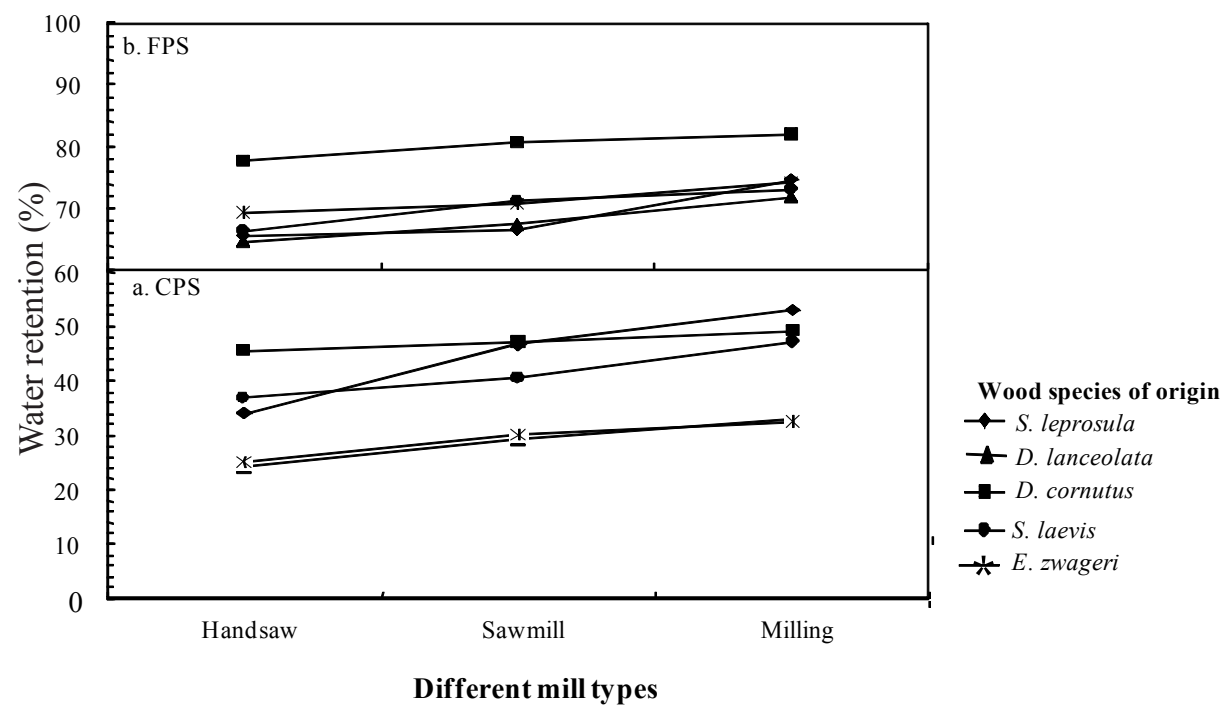

Figure 4. Water retention (\%) of sawdust samples from five tropical wood species using different mill types and scrutinized by particle size classes $(\mathrm{CPS}=\mathrm{a}$; FPS $=\mathrm{b}$ ). 


\section{E. Influential Factors on Porosity and Water Retention}

In porosity, particle density had a strong influence $(F$-test $=13.21, P$-value $=$ 0.0013 ) while the mill type, particle size classes and wood density had a lower degree of significance on variation in porosity (Table 2). It is assumed that this pattern caused by particle density may be ascribed to the inter-space among and intra-space within particles (e.g. wood pores and wood species). Sawdust with low porosity may be due to high particle density or conversely it can be assumed that sawdust with low particle density will be high in porosity.

Table 2. Summary of generalized linear model (GLM) analysis for potential influential factors affecting porosity and water retention of sawdust.

\begin{tabular}{lllll}
\hline \multirow{2}{*}{\multicolumn{1}{c}{$\begin{array}{c}\text { Explanatory } \\
\text { Variables }\end{array}$}} & \multicolumn{3}{c}{ Dependent variables } \\
\cline { 2 - 5 } & \multicolumn{3}{c}{ Porosity } & \multicolumn{2}{c}{ Water retention } \\
\cline { 2 - 5 } & $F$-test & $P$-value & $F$-test & $P$-value \\
\hline Mill types & 2.86 & 0.077 & 1.45 & 0.255 \\
Particle size & 3.37 & 0.077 & 117.58 & $0.000^{* *}$ \\
Wood density & 3.68 & 0.067 & 4.11 & 0.054 \\
Particle density & 13.21 & $0.001^{* *}$ & 1.82 & 0.189 \\
\hline
\end{tabular}

Onto water retention, only particle size classes showed significant influence $(F$-test $=117.58, P$-value $<0.001)$, while wood density was marginal $(F$-test $=4.11, P$-value $=0.05)$ and the influence of different mill types and particle density was negligible (Table 2).

\section{CONCLUSION}

The use of mills with larger knife sizes (in decreasing order from the largest; handsaw, sawmill, and mill) tends to produce sawdust with greater proportion of larger particle size (in decreasing order OS, CPS, and FPS); and vice versa for the smaller knife size. Wood species with greater density produced sawdust with greater particle density as well. Meanwhile, the particle density of FPS tends to be larger than that of CPS. Sawdust with greater particle density and greater density of wood origin tends to exert low porosity and low water retention and vice versa. Further, sawdust with larger particle size (CPS) afforded less-intensity and lower water retention. Furthermore, the porosity and water retention of CPS is less than those of FPS. Smaller particle size will retain more water than larger particle size, therefore, a decrease in particle size will increase particle adhesion of sawdust. It can, therefore, be concluded that particle density essentially influences porosity, and particle size influences water retentions. 


\section{ACKNOWLEDGEMENT}

The authors would like to deeply appreciate the Tropical Forest Research Center of Mulawarman University, C.V. Perjuangan Sawmill Industry and Sumalindo Lestari Timber Company for providing the research material. Further appreciation is extended to the Laboratory of Wood Chemistry of Mulawarman University, Dipterocarp Research Center of Kalimantan, and Laboratory of Forest Product, Forest Product Research Institute of Asahikawa, Hokkaido, Japan which have provided valuable supports during the laboratory work. Also, special gratitude goes to Ii Sumirat, Uus Suhendar and Syahrir for their assistance during data collection. Financial support from the Japan Society for the Promotion of Science (JSPS\#19255016) is gratefully acknowledged. Part of this study was presented at the International Seminar on Sustainable Biomass Production and Utilization: Challenges and Opportunities, 3-4 August 2009, Lampung, Indonesia. The authors also appreciate Iswandi Anas, Yaya Rayadin and Eleanor Clark for critical scrutiny on the earlier draft of this manuscript.

\section{REFERENCES}

Afuwape, F.K. 1983. Design and testing of a sawdust compactor. B.Sc. Thesis, Department of Agricultural Engineering. Obafemi Awolowo University, Lie-Ife. Nigeria.

Agnew, J.M. and J.J. Leonard. 2003. The physical properties of compost (Literature Review). Compost Science and Utilization 11:238-264.

Araki, Y. and M. Terazawa. 2004. Physical properties of sawdust and soil (in Japanese). In: Proceedings of the Hokkaido Branch of Japan Wood Research Society 36, 67-70.

Baker, S.M., T.L. Richard, Z. Zhang and S. Monteiro da Rocha. 1998. Determining the free air space inside compost mixtures using a gas pycnometer. American Society Agricultural Engineering (paper no 984094).

Bergström, D., S. Israelsson, M. Öhman, S.A Dahlquist, R. Gref, C. Boman and Wästerlund. 2008. Effects of raw material particle size distribution on the characteristics of Scots pine sawdust fuel pellets (Article in press). Fuel Processing Technology 6 .

Bouma, J., P.S.C. Rao and R.B. Brown. 2003a. Soil as a porous medium: Basics of soil-water relationships-Part I. Reviewed: September 2003 (adopted in July 17, 2005), University of Florida, IFAS extension, USA. <http://www.edis.ifas.ufl. edu/SS108>.

Bouma, J., P.S.C. Rao and R.B. Brown. 2003b. Retention of water: Basics of soil-water relationships-Part II. Reviewed: September 2003 (adopted in July 17, 2005), University of Florida, IFAS extension, USA. <http://www.edis.ifas.ufl.edu/ SS109>. 
Coudray, N., A. Dieterlen, E. Roth and G. Trouve. 2009. Density measurement of fine aerosol fractions from wood combustion sources using ELPI distributions and image processing techniques. Fuel Processing Technology 88: 947-954.

Dikinya, O., C. Hinz and G. Aylmore. 2006. Dispersion and re-deposition of fine particles and their effects on saturated hydraulic conductivity. Australian Journal of Soil Research 44: 47-56.

Frombo, F., R. Minciardi, M. Robba, F. Rosso and Sacile. 2009. Planning woody biomass logistics for energy production: A strategic decision model. Biomass and Bioenergy 33: 372-83.

Himmel, M., M. Tucker, J. Baker, K. Rivard, and K. Grohmann. 1985. Communition of biomass: hammer and knife mills. In: Proceedings of Biotechnology and Bioengineering Symposium 15.

Horisawa, S., M. Sunagawa, Y. Tamai, Y. Matsuoka, T. Miura and M. Terazawa. 1999. Biodegradation of nonlignocellulosic substances II: Physical and chemical properties of sawdust before and after use as artificial soil. Journal of Wood Science 45: 492-497.

Houghton, J.I., J.E. Burgess and T. Stephenson. 2002. Off-line particle size analysis of digested sludge. Water Resources 36: 4643-4647.

Hwang, S.I., K.P. Lee, D.S. Lee and S.E. Powers. 2002. Models for estimating soil particle-size distributions. Soil Science Society of America Journal 66: 1143-1150.

Johnson, G.R., B.L. Gartner, D. Maguire and A. Kanaskie. 2003. Influence of bravo fungicide application on wood density and moisture content of Swiss needle cast affected Douglas-fir trees. Forest ecology and Management 186: 339-348.

Kitsui, T. and M. Terazawa. 1999. Bio-toilet environmentally-friendly toilets for the 21 century (dry closet using sawdust as an artificial soil matrix). In: Proceedings of international symposium of bio-recycling/composting. 6-8 September, Sapporo, Japan.

MFoR (The Ministry of Forestry Republic of Indonesia). 2007. Forestry statistics of Indonesia year 2006. Jakarta, Indonesia. <http://www.dephut.go.id/ INFORMASI/STATISTIK/2006/.

Paulrud, S., J.E. Mattsson and C. Nillson. 2002. Particle and handling characteristics of wood fuel powder: effects of different mills. Fuel Processing Technology 76: 23-39.

Rühlmann, J., M. Körschens and J. Graefe. 2006. A new approach to calculate the particle density of soils considering properties of the soil organic matter and the mineral matrix. Geoderma 130: 272-283.

SAS Institute Inc. 2007. JMP 7.0.1 Help. SAS Institute Inc, Cary,NC. 
Terazawa, M., S. Horisawa, Y. Tamai and K. Yamashita. 1999. Biodegradation of lignocellulosic substance I: System for complete degradation of garbage using sawdust and aerobic soil bacteria. Journal of Wood Science 45: 354-358.

Terazawa, M. 2003. Sawdust Saves Globe - Bioconversion of biomass wastes into multifunctional recyclates using sawdust as an artificial soil matrix. In: Proceedings of the $1^{\text {st }}$ International Symposium on Sustainable Sanitation, Nanjing, China (1): 9-12.

Zavala, M.A.L., N. Funamizu and T. Takakuwa. 2004. Modeling of aerobic biodegradation of feces using sawdust as a matrix. Water Resources 38: 1327-1339. 